\title{
PTPRN Gene
}

National Cancer Institute

\section{Source}

National Cancer Institute. PTPRN Gene. NCI Thesaurus. Code C148306.

This gene is involved in the regulation of neurotransmitter, pituitary hormone and insulin secretion. 